\title{
Studi Kinetika Degradasi Zat Organik pada Reaktor Hibrid Anaerob
}

Oleh Gede H. Cahyana, M.T dan Asis H. Djajadiningrat

\begin{abstract}
Abstrak
Telah dilaksanakan studi kinetika pada Reaktor Hibrid Anaerob (Rehan) dengan mode kontinyu dan asumsi regim alirannya adalah CSTR seri. Sejumlah nilai parameter kinetika diperoleh sebagai berikut. Jika zone pertumbuhan terlekat dianggap tidak berperan karena reduksi COD-nya sangat kecil maka nilai parameter kinetikanya tanpa koreksi volume ialah $\mu_{m}=0,2982 / j a m k_{d}=-0,0479 / j a m, K=-$ 0,2443 dan $Y=5,1515$. Jika ada koreksi volume, nilainya menjadi $\mu_{m}=0,3472 / j a m$, $k_{d}=-0,0479 / \mathrm{jam}, K=-0,2410$ dan $Y=5,1515$. Jika zone tersebut dianggap berperan maka nilai parameter kinetikanya di zone tersuspensi tanpa koreksi volume ialah $\mu_{m}$ $=0,0890 / \mathrm{jam}, k_{d}=-0,1929 / \mathrm{jam}, K=-0,3821$ dan $Y=3,1342$. Untuk zone terlekat adalah $K=0,4804$ dan $G=0,0089$ (m/jam). Jika volumenya dikoreksi, nilainya : $\mu_{m}=$ $0,1608 / \mathrm{jam}, k_{d}=-0,1929 / \mathrm{jam}, K=-0,3325, \quad Y=3,1342$ dan zone terlekat $K=0,4486$ dan $\mathrm{G}=0,0083(\mathrm{~m} / \mathrm{jam})$.
\end{abstract}

Kata penting : Rehan, tersuspensi, terlekat, model kinetika

\section{Pendahuluan}

Telah banyak dilakukan studi kinetika degradasi zat organik pada berbagai jenis reactor, baik batch maupun kontinyu dengan variasi regime teraduk sempurna (CSTR) dan plug flow. Studi kinetika pada reaktor generasi pertama seperti anaerobic digester dan anaerobic contact process dan reaktor generasi kedua seperti UASB (upflow anaerobic sludge blanket) dan biofilter telah banyak dilakukan. Sedangkan penelitian tentang kinetika reaktor hibrid anaerob (singkat: Rehan) khususnya bermedia batu, relatif sedikit karena lebih banyak fokus pada kinerjanya (performance).

\section{Tujuan Penelitian}

Penelitian ini ditujukan untuk memperoleh sejumlah nilai parameter kinetika dengan menggunakan model kinetika Chen - Hashimoto dan model Atkinson.

\section{Tinjauan Kepustakaan}

Kinetika reaksi berperan penting pada unit pengolah biologi yang didasarkan pada proses mikrobiokimia khususnya pada analisis proses, kontrol dan desain unit pengolah air limbah. Hal ini dapat digunakan untuk optimasi proses, stabilisasi operasi dan kontrol yang lebih baik dengan landasan kinetika pertumbuhan biologi, yaitu laju pertumbuhan mikroba dan laju pemanfaatan substrat. 
Sampai saat ini, belum banyak ditemukan literatur Rehan yang menyajikan kinetika reaksinya. Yang ada lebih condong pada hidrodinamika dan kinerja (performance) reaktor. Namun demikian, sebagai pembanding dikutipkan hasil penelitian Ariani (1999) untuk reaktor hibrid anaerob bermedia bambu. Parameter kinetika di zone tersuspensi yang diperolehnya adalah $\mu_{\mathrm{m}}=1,1059 / \mathrm{hari}, \mathrm{K}_{\mathrm{s}}=1076 \mathrm{mg} / \mathrm{L}, \mathrm{Y}=$ $0,214674, K_{d}=0,8038 /$ hari, $K_{m}=8245 \mathrm{mg} / \mathrm{L}$ dan untuk zone terlekatnya adalah $\mu_{m}=1,4936 /$ hari, $K_{s}=9081 \mathrm{mg} / \mathrm{L}, Y=0,02991, K_{d}=1,8216 /$ hari dan $K_{m}=64741 \mathrm{mg} / \mathrm{L}$.

Meskipun demikian, secara umum telah ada sejumlah nilai parameter kinetika proses anaerob seperti diperlihatkan pada Tabel 1, untuk nilai tipikal faktor Yield.

Tabel 1. Yield biomassa pada sejumlah zat organik

\begin{tabular}{|l|c|}
\hline \multicolumn{1}{|c|}{$\begin{array}{c}\text { Jenis zat } \\
\text { organik }\end{array}$} & $\begin{array}{c}\text { Yield } \\
\text { (g sel/g COD tersisinkan) }\end{array}$ \\
\hline Karbohidrat & 0,350 \\
\hline Protein & 0,205 \\
\hline Asetat & 0,032 \\
\hline Propionat & 0,037 \\
\hline Butirat & 0,058 \\
\hline H2 & 0,030 \\
\hline Lemak & 0,038 \\
\hline
\end{tabular}

Sumber : Pavlostathis-Gomes (1991).

Sedangkan rentang tipikal konstanta kinetika pada sejumlah substrat diberikan pada Tabel 2, yang terjadi pada kondisi mesofilik.

Tabel 2. Nilai konstanta kinetika zat organik pada proses anaerob mesofilik.

\begin{tabular}{|l|l|c|c|c|c|}
\hline Substrat & Proses & $\begin{array}{c}\text { Ks } \\
\mathbf{m g ~ C O D / L}\end{array}$ & $\begin{array}{c}\mu_{\mathrm{m}} \\
(\mathbf{1} / \text { hari) }\end{array}$ & $\begin{array}{c}\mathbf{Y} \\
\text { (g VSS/gCOD) }\end{array}$ & $\begin{array}{c}\mathbf{k}_{\mathbf{d}} \\
(\mathbf{1} / \mathbf{h a r i})\end{array}$ \\
\hline $\begin{array}{l}\text { Karbo- } \\
\text { hidrat }\end{array}$ & $\begin{array}{l}\text { Asido } \\
\text { genesis }\end{array}$ & $22,5-630$ & $7,2-30$ & $0,14-0,17$ & 6,1 \\
\hline ALRP & $\begin{array}{l}\text { Oksidasi } \\
\text { anaerob }\end{array}$ & $105-3180$ & $0,085-0,55$ & $0,04-0,11$ & $0,01-0,015$ \\
\hline ALRD & $\begin{array}{l}\text { Oksidasi } \\
\text { anaerob }\end{array}$ & $12-500$ & $0,13-1,20$ & $0,025-0,047$ & $0,004-0,037$ \\
\hline Asetat & MA & $2,6-11,6$ & $0,08-0,7$ & $0,01-0,054$ & 0,088 \\
\hline
\end{tabular}

Sumber: Speece (1996) dari Pavlostathis-Gomes (1991).

Keterangan $\quad: A L R P$ : asam lemak rantai panjang

$A L R D$ : asam lemak rantai pendek

$M A$ : Metanogenesis asetiklastik 
Model kinetika yang digunakan untuk mendapatkan nilai parameter kinetika proses adalah model Chen-Hashimoto yaitu: $\mu=\frac{\mu_{m} S}{K S_{0}+(1-K) S}$

Asumsinya adalah (a) reaktor dalam kondisi tunak, (b) secara keseluruhan pola aliran reaktor adalah plug flow namun setiap partisi reaktor berlaku seperti CSTR seri sehingga memungkinkan untuk menerapkan pola CSTR pada partisi tersebut untuk penyusunan neraca massa, (c) kinetika mengikuti formulasi Chen-Hashimoto, (d) umpan tidak mengandung biomassa kecuali pada mode resirkulasi.

(1). Model pertumbuhan tersuspensi.

Untuk substrat :

$S=\frac{K S_{0}\left(1+k_{d} \theta\right)}{(K-1)\left(1+k_{d} \theta\right)+\mu_{m} \theta}$

Untuk biomassa :

$X=\frac{Y\left(S_{0}-S\right)}{1+k_{d} \theta}$

(2). Model pertumbuhan terlekat.

Atkinson berasumsi bahwa laju reaksi dikendalikan oleh difusi substrat ke biofilm (lapisan bakteri) dan tidak ada gradien konsentrasi substrat ketika menembus lapisan air (liquid film) menuju biofilm. Jika digabungkan dengan model kinetika Chen-Hashimoto akan diperoleh model seperti persamaan (4) dan (5).

$$
\begin{aligned}
& r_{s u}=\frac{-q_{m} X S}{K S_{0}+(1-K) S} \\
& r_{s u}=\frac{-q_{m} f h S(S)}{K S_{0}+(1-K) S}
\end{aligned}
$$

$\mathrm{q}_{\mathrm{m}}=$ maximum substrate utilization rate $[1 / \mathrm{jam}]$

$\mathrm{r}_{\mathrm{su}}=$ substrate utilization rate. $[\mathrm{mg} / \mathrm{L} . \mathrm{jam}]$

$X=$ biomassa terlekat $=$ f.h.S. $[\mathrm{mg} / \mathrm{L}]$

$f=$ faktor proporsionalitas

$\mathrm{h}=$ tebal biofilm $[\mathrm{m}]$

$\mathrm{S}=$ konsentrasi substrat di bagian cair (liquid). [mg/L]

$\mathrm{D}=$ tinggi media $[\mathrm{m}]$

$\mathrm{w}=$ diameter reaktor $[\mathrm{m}]$ 
Diperoleh persamaan:

$$
\begin{aligned}
& \frac{Q}{D w} \ln \frac{S}{S_{0}}=\frac{-K}{(1-K)} \frac{Q\left(\frac{S_{0}}{S}-1\right)}{D w}+\frac{-f q_{m} h}{(1-K)} \\
& \left(\mathrm{fq}_{\mathrm{m}} \mathrm{h}\right)=\mathrm{G}(\mathrm{m} / \mathrm{jam}) .
\end{aligned}
$$

\section{Metode dan bahan}

Reaktor Hibrid Anaerob dibuat dari pipa PVC, terdiri atas dua bagian, yaitu bagian bawah berdiameter $20 \mathrm{~cm}$, tinggi $35 \mathrm{~cm}$ untuk pertumbuhan tersuspensi dengan volume total $14,4 \mathrm{~L}$. Adapun diameter bagian atas adalah $25 \mathrm{~cm}$, tinggi efektif 110 $\mathrm{cm}$ dan diisi kerikil berukuran $2-3 \mathrm{~cm}$ sebagai media pertumbuhan lekat (identik dengan anaerobic filter atau fixed bed atau biofilter). Parasitas reaktor (perviousness, bukan porosity) $\approx 0,50$ sehingga volume efektifnya (void volume) menjadi 27,15 L. Debit air limbah untuk waktu tinggal hidrolis 30 jam sekitar 23 $\mathrm{ml} / \mathrm{menit}$.

\section{Hasil dan pembahasan}

Nilai parameter kinetika reaktor diperoleh berdasarkan formula yang telah disebutkan pada tinjauan kepustakaan. Karena Rehan adalah reaktor bastar (hybrid), yakni gabungan dua reaktor yang masing-masing karakteristiknya berbeda maka dibuat dua macam perhitungan kinetika. Yang pertama dengan anggapan zone terlekat berperan dan yang kedua dengan anggapan zone terlekat tidak berperan dalam mereduksi COD.

\section{(1). Pertumbuhan terlekat diasumsikan berperan}

Jika zone terlekat diasumsikan berperan dalam mereduksi COD maka diperlukan dua formula yang berbeda, satu formula untuk bagian tersuspensi dan satu lagi untuk pertumbuhan lekat. Keduanya tetap menggunakan model kinetika ChenHashimoto namun zone terlekat didekati dengan formula Atkinson yang serupa dengan usulan Eckenfelder untuk pembahasan Trickling Filter.

Nilai parameter kinetikanya tanpa koreksi volume ialah $\mu_{m}=0,0890 / j a m, k_{d}=-0,1929$ /jam, $\mathrm{K}=-0,3821$ dan $\mathrm{Y}=3,1342$ dan untuk zone terlekatnya $\mathrm{K}=0,4804$ dan $\mathrm{G}=$ 0,0089 (m/jam). Jika dilakukan koreksi volume maka nilainya ialah $\mu_{\mathrm{m}}=0,1608 / \mathrm{jam}$, $\mathrm{k}_{\mathrm{d}}=-0,1929 / \mathrm{jam}, \mathrm{K}=-0,3325$ dan $\mathrm{Y}=3,1342$ dan bagian terlekatnya adalah $\mathrm{K}=$ 
0,4486 dan $\mathrm{G}=0,0083$ ( $\mathrm{m} / \mathrm{jam})$. Diperoleh nilai $\mu_{\mathrm{m}}$ dan $\mathrm{K}$ dengan koreksi volume lebih besar daripada tanpa koreksi volume.

\section{(2). Pertumbuhan terlekat diasumsikan tidak berperan.}

Asumsi ini diambil karena reduksi COD di zone terlekat sangat kecil padahal waktu tinggal hidrolisnya besar, lebih dari dua kali waktu tinggal hidrolis di zone tersuspensi. Logikanya, reduksi COD seharusnya lebih besar di zone lekat. Tapi ini tidak terjadi. Bahkan tidak ada reduksi COD di segmen P4 - outlet pada beban $10.330 \mathrm{mg} / \mathrm{L}$ dengan $\mathrm{R}=0,71$. Hasil perhitungan kinetikanya, sebagai berikut.

Nilai parameter kinetikanya tanpa koreksi volume, $\mu_{m}=0,2982 / \mathrm{jam}, \mathrm{kd}=-0,0479 / \mathrm{jam}$, $K=-0,2443$ dan $Y=5,1515$. Jika ada koreksi volume, nilainya menjadi $\mu_{m}=$ $0,3472 / \mathrm{jam}, \mathrm{k}_{d}=-0,0479 / \mathrm{jam}, \mathrm{K}=-0,2410$ dan $\mathrm{Y}=5,1515$. Terlihat pula nilai $\mu_{\mathrm{m}}$ dan $\mathrm{K}$ pada koreksi volume lebih besar daripada tanpa koreksi volume.

Dari keempat macam mode perhitungan tersebut, nilai $k_{d}$ di zone tersuspensi selalu negatif. Artinya, di dalam Rehan selalu terjadi pertumbuhan netto yang lebih besar dari nol atau laju pertumbuhannya lebih besar daripada laju kematian dan peluruhan. Ini menunjukkan bahwa konsentrasi biomassa dan pertumbuhannya lebih besar sehingga efisiensi penyisihan COD-nya juga lebih besar.

Jika dibandingkan dengan nilai faktor hasil (Yield) dari Pavlostathis-Gomes (1991), nilai $Y$ pada penelitian Rehan ini lebih besar untuk substrat yang sama, yakni karbohidrat (molasse). Sedangkan nilai $\mu_{\mathrm{m}}$-nya jika pertumbuhan terlekat ikut berperan, berada di dalam rentang substrat asam lemak rantai pendek. Namun jika pertumbuhan terlekat diasumsikan tidak berperan maka nilainya di dalam rentang asam lemak rantai panjang.

Untuk parameter yang lain (khususnya zone terlekat) tidak dapat dibandingkan karena menggunakan model kinetika yang berbeda dengan penelitian ini dan sejumlah parameter kinetika belum ditemukan pada bahasan sejumlah peneliti lain. Termasuk formulasi zone terlekat yang diambil dari modifikasi formula Atkinson yang berbeda dengan pendekatan peneliti lainnya. 


\section{Kesimpulan}

Sejumlah nilai parameter kinetika Rehan berada pada rentang asam lemak rantai panjang dan asam lemak rantai pendek. Namun semua koefisien Yield-nya ( $\mathrm{Y}$ ) relatif lebih besar daripada koefisien Yield substrat karbohidrat yang dilaporkan oleh sejumlah peneliti yang menggunakan reaktor UASB. Dengan demikian, model kinetika Chen-Hashimoto dan neraca massa pertumbuhan tersuspensi dan terlekat masih dapat diterapkan pada Rehan.

\section{Saran}

Hendaknya dilakukan penelitian dengan menggunakan formula kinetika yang lain, khususnya di zone terlekat untuk melihat apakah bagian ini signifikan ataukah tidak dalam mereduksi COD dengan regime aliran plug flow. *

\section{Daftar Pustaka}

Ariani D. A. (1999). Model Matematika Penyisihan Substrat dalam Reaktor Upflow Hibrid Anaerobik yang Mengolah Air Buangan Mengandung Organik Tinggi. Tesis Magister, Jurusan Teknik Lingkungan, ITB.

Carrondo M., Siva, Figueira, Ganho, Oliveira (1983). "Anaerobic Filter Treatment of Molasses Fermentation Wastewater." Water Scie. and Technology, Vol. 15, p. 117-126.

Hall E. (1992) "Anaerobic Treatment of Wastewater in Suspended Growth and Fixed Film Process." Design of Anaerobic Processes for the Treatment of Industrial and Municipal Wastes. Ed. Malina J.F., Pohland F.G. Technomic Publishing Company. Inc, USA.

Joubert W., T. J. Britz. (1987). "The Performance and Mixing Characteristic of an Anaerobic Hybrid Reactor Treating a Synthetic Fatty Acid Containing Substrate." Water SA,Vol. 13, p.63- 68.

Ozturk I., et al. (1993). "Hybrid Upflow Anaerobic Sludge Blanket Reactor (HUASBR) Treatment of Dairy Effluents." Wat. Sci. Tech., Vol. 28, p. 77-85.

Pavlostathis, Gomes (1991), Kinetics of Anaerobic Treatment: A Critical Review. Critical Review in Environmental Control 21(5,6) : 411-490.

Speece R.E. (1996). Anaerobic Biotechnology for Industrial Wastewater. Archae Press, Vanderbilt University, England.

Sukartono (1996). Pengaruh Variasi Waktu Detensi Terhadap Degradasi Glukosa Beban Tinggi pada Bioreaktor Upflow Hibrid Anaerob Media Bambu dengan Acuan Industri Etanol. Jurusan Teknik Lingkungan ITB.

Dipublikasikan di Majalah Kopertis Wilayah IV: Wawasan Tridarma, 2001, 0215-8256, hal. 28-31. 